Journal of Applied Philosophy, vol. 32, núm. 4, 2015, pp. 432-439.

\title{
Eroding Capitalism: A Comment on Stuart White's 'Basic Capital in the Egalitarian Toolkit'.
}

\author{
Wright, Erik Olin.
}

Cita:

Wright, Erik Olin (2015). Eroding Capitalism: A Comment on Stuart White's 'Basic Capital in the Egalitarian Toolkit'. Journal of Applied Philosophy, 32 (4), 432-439.

Dirección estable: https://www.aacademica.org/erik.olin.wright/3 ARK: https://n2t.net/ark:/13683/paqp/Fun 


\section{Eroding Capitalism: A Comment on Stuart White's 'Basic Capital in the Egalitarian Toolkit'}

\section{ERIK OLIN WRIGHT}

ABSTRACT Stuart White argues that egalitarians need a diverse toolkit of policy proposals in order to move closer to a just economic system. In particular he argues that a policy of Basic Capital grants should be included in this toolkit along with a variety of other more familiar instruments such as unconditional Basic Income, welfare state services and income supports, and support for worker cooperatives. The various policies in the egalitarian toolkit, however, have implications for issues other than contributing to a more just economic system. In particular, they have implications for the long term stability, transformation, or even transcendence, of capitalism as an economic system. In this article I will argue that unconditional Basic Income has a greater potential to erode capitalism than does Basic Capital. While both of these policies in the egalitarian toolkit may make the economic system statically more just, over time Basic Capital grants are likely to strengthen capitalism as the core structure of the economic system, whereas unconditional Basic Income has the potential to erode the dominance of capitalism. As part of a long-term project of human emancipation, therefore, unconditional Basic Income should have priority over Basic Capital.

In his essay 'Basic Capital in the Egalitarian Toolkit', Stuart White argues that egalitarians need a diverse toolkit of policy proposals in order to move closer to a just economic system. In particular he argues that a policy of Basic Capital grants should be included in this toolkit along with a variety of other more familiar instruments such as Unconditional Basic Income, welfare state services and income supports, and support for worker cooperatives. There are two basic reasons for this claim. First, because of the complexity of issues involved in both creating and sustaining a more just society, no single policy mechanism is likely to be adequate to the task. And second, because of political and cultural factors that vary across contexts, different mixes of policies are likely to be more achievable in different times and places. While it may well be that some policies are more broadly useful than others for advancing egalitarian goals, the specific relevance of any one kind of policy will be largely an empirical issue. In the specific case of Basic Capital grants, the basic argument in favour of its inclusion in the egalitarian toolkit is the ways in which it creates a more egalitarian terrain for young adults to engage in big projects that are especially important for ambition formation. These arguments are eminently sensible when policies are treated exclusively in terms of their immediate effects on the justice of an economic system.

The various policies in the egalitarian toolkit, however, have implications for issues other than contributing to a more just economic system. In particular, they have implications for the long term stability, transformation, or even transcendence, of 
capitalism as an economic system. In this paper I will argue that Unconditional Basic Income has a greater potential to erode capitalism than does Basic Capital. While both of these policies in the egalitarian toolkit may make the economic system statically more just, over time Basic Capital grants are likely to strengthen capitalism as the core structure of the economic system, whereas Unconditional Basic Income has the potential to erode the dominance of capitalism. As part of a long-term project of human emancipation, therefore, Unconditional Basic Income should have priority over Basic Capital.

In Section 1 I will set the stage for this analysis by briefly discussing the critique of capitalism and its connection to liberal egalitarianism. Section 2 will explain the theoretical idea of 'eroding' capitalism. Section 3 will explore the ways in which Basic Capital might strengthen the reproduction of capitalism while Basic Income has the potential of eroding its dominance.

\section{Liberal Egalitarianism and the Critique of Capitalism}

Capitalism is a specific way of organising the 'rules of the game' of an economic system. It is defined by three principal conditions: first, production is organised for the market; second, the means of production are privately owned and investment is privately controlled; and third, the people who use those means of production to produce goods and services - that is, the workers - are hired on a labour market to work in firms as employees. When defined in this way, capitalism is not identical to the idea of a market economy. To be sure, capitalism is organised through markets; but not all market economies are capitalist.

There are many possible grounds for criticising capitalism: ${ }^{1}$ the unjust inequalities capitalism systematically generates; the undemocratic features that are inherent in private ownership and control of production, since privately-allocated investment necessarily excludes important matters of public concern from meaningful popular democratic control; ${ }^{2}$ the damage to the environment, both because of capitalist dynamics of endless growth and because of the strong tendencies of profit-maximising firms to generate negative environmental externalities; and the tendency of capitalism to undermine human flourishing through the ways it shapes identities and conceptions of the good, for example through its promotion of consumerism and hyper-competitive individualism. ${ }^{3}$

To the extent that eliminating these harms requires state action and public policies, these kinds of criticisms of capitalism are in some tension with certain liberal arguments about state neutrality. ${ }^{4}$ It is fairly straightforward to show the ways in which capitalism as an economic system promotes consumerism and hyper-competitive individualism on the one hand and undermines a strong sense of community solidarity on the other. A critique of these systemic biases in terms of justice would argue that capitalism, by virtue of these biases, creates an unjust distribution of opportunities for people to choose certain ways of life. The critique in terms of general harms is that capitalism creates ways of life that are undesirable for human flourishing even apart from the distribution of access to those ways of life. This problem cannot be solved simply by moving towards a more egalitarian distribution of opportunities to choose to live in whatever variations in community, competitiveness and consumerism 
are available in the existing society; the problem is that capitalism as a system pervasively shapes what is available in the first place and people's preferences across these alternatives. ${ }^{5}$ But liberal egalitarians, for good reason, are suspicious of using state power to oppose particular ways of life, so long as these ways of life do not violate principles of justice. So, while it is perfectly fine to criticise capitalism on the grounds of consumerism, competitive individualism and degraded community, in much liberal reasoning this does not provide sufficient grounds for the state to purposively intervene to do anything about these issues. The state should be neutral, and least in terms of its intentions, with respect to alternative ways of life.

But here's the problem: there is no meaningful neutral position possible. This is true both because of the ways in which capitalism shapes the preferences and identities of individuals and because of the way it systematically affects the social environments available to individuals. The state's enforcement of the private property rights that make a capitalist market economy possible empirically favours some ways of life over others and some preferences over others. One can say, as liberals sometimes do, that this bias is merely a 'side effect' of protecting capitalist private property rights rather than the state's purpose; all that really matters is intent. But once one knows that such side effects exist and that they are unavoidable, then in practical terms the idea of state neutrality becomes quite precarious. Equally, of course, if the state promotes non-capitalist forms of economic organisation it generates biases towards alternative ways of life. Given this, it seems better to try to balance in some way the liberal principle of avoiding forcing people to do things on grounds they cannot accept, with the idea of pursuing policies that facilitate ways of life conducive to human flourishing.

I will not enter the complex terrain of debates over the meaning of liberal neutrality and its implications in a world where preferences for ways of life and available social environments are systematically shaped by social processes. Without further argument, the discussion which follows will assume that capitalism generates real harms that can be understood both in terms of injustice and in terms of impediments to human flourishing. These harms provide grounds for the political project of transforming capitalism.

\section{Eroding Capitalism}

Traditionally, radical critics of capitalism have adopted one or the other of two logics of transformation: smashing capitalism or taming capitalism. The first of these corresponds to the grand visions of revolutionary socialism and communism. The strategic objective is a ruptural seizure of state power, followed by a coercive dissolution of capitalist structures and institutions and their replacement by an emancipatory alternative. After the historical experiences of attempts at such ruptural strategies in the $20^{\text {th }}$ century, few people give much credibility to this scenario, even when they remain sharply critical of capitalism itself. The goal of taming capitalism has been the hallmark of traditional social democracy. The idea of what might be termed symbiotic strategies of transformation was to create new institutional devices that would simultaneously solve problems in the erratic functioning of capitalism (and thus serve the interests of elites) and neutralise its most harmful effects on the lives of ordinary people (and thus serve the interests of the masses). While such symbiotic strategies retain more plausibility than ruptural strategies, their effectiveness has been undermined in recent decades by the globalisation and financialisation of capitalism. 
There is a third logic of transformation that is gaining increasing attention: eroding capitalism by building emancipatory alternatives in the spaces and cracks within capitalist economies and struggling to defend and expand those spaces. The premise of such interstitial strategies is that all economic systems are really hybrids of many different kinds of economic relations, practices and institutions. What we call a 'capitalist economy' is more properly understood as an economic system in which capitalism is dominant but coexists with all sorts of non-capitalist forms of economic organisation and activity. In addition to traditional publicly-owned organisations for the production and distribution of goods and services (libraries, medical care, education, public transportation, etc.) there are worker-owned cooperatives, sometimes integrated into something like a cooperative market sector; non-profit organisations engaged in economic activities; peer-to-peer networks in a collaborative commons; land-trusts used for such things as community gardens and affordable housing; and a wide variety of forms that are grouped under the rubric 'the social economy'. All of these in different ways can be thought of as building blocks of an alternative economy organised around democratic egalitarian principles. What an interstitial strategy proposes, then, is that in the long term, capitalism could be transformed — eroded — and potentially superseded by a more emancipatory alternative through the steady expansion of these non-capitalist, democratic, egalitarian forms of economic life. ${ }^{6}$

Given the implausibility of ruptural strategies in the world today, the only real prospect for challenging capitalism involves some combination of symbiotic and interstitial strategies. Traditional social democratic politics focused almost exclusively on the first of these, through top-down initiatives by the state to provide services, insure people against risks, and regulate capitalist firms and markets. What is needed is a strategic vision which uses the state to solve practical problems within capitalism but does so in a way that expands the space and energy for interstitial strategies as well.

\section{Basic Capital and Basic Income as Symbiotic Reforms}

Both Unconditional Basic Income (UBI) and Basic Capital (BC) are reforms in the mechanisms through which the state shapes the distribution of income and wealth: UBI gives every person unconditionally a modest regular income; BC gives every adult a lump-sum capital grant. Both reforms are justice-enhancing, but I won't debate the issue of which is likely to move us closer to a just society. Obviously the impact on justice depends in part on the magnitude of each of these and in part on a wide range of contingent factors in the specific contexts where they might be instituted. I also won't discuss the economic viability of either policy. Again, this clearly depends on the magnitudes involved. What I will assume is that a modest, no-frills Basic Income sufficient to put people above the poverty line is viable, as is a Basic Capital grant sufficient to provide a significant capacity to form long-term 'ambitious' plans. ${ }^{7}$

The question I want to address is the implications of these alternative egalitarian policies for the potential erosion of the dominance of capitalism within an economic system.

First let's examine Basic Income. ${ }^{8}$ A regular, guaranteed, Unconditional Basic Income above the poverty line given to every adult constitutes a fundamental transformation of the nature of labour markets in capitalism. One of the defining characteristics of 
capitalism is that workers are separated from the means of production and by virtue of this, separated from the means of subsistence. This double separation is what Marxists have called the process of proletarianisation. As a result, workers must seek employment from owners of the means of production in order to gain a livelihood. This is the essence of what is sometimes called 'proletarian unfreedom'. ${ }^{9}$ A UBI connects all people to the means of subsistence without the necessity of owning the means of production. It constitutes a radical deproletarianisation of the labour force and thus a partial transformation of the class relations of capitalism.

From the point of view of the potential for interstitial transformations, UBI gives people the freedom to say 'no' to capitalist employment and devote their energies to alternative forms of economic activity. ${ }^{10}$ One of the principle constraints on the development of nonmarket-oriented economic activity (such as $\mathrm{p} 2 \mathrm{p}$ collaborative network production, the needs-oriented social economy, and non-commercial performing arts) is the difficulty in making a living from these activities. Many of these activities require relatively little capital, but the participants do need an income to cover basic needs. By providing a Basic Income independent of market exchange, UBI opens up much greater time for people to engage in these decommodified alternative economic forms and expand the nonmarket, nonstate sectors of the economy.

UBI also increases the viability of certain noncapitalist forms of market activity. Consider worker-owned cooperatives. One of the major constraints on the formation of worker cooperatives is the difficulty of workers obtaining loans through conventional credit markets. To some extent this may reflect biases by banks against worker-owners, but more fundamentally this simply reflects the fact that workers typically have no collateral and thus their businesses — like most small businesses — are risky. Furthermore, the fact is that workers have to eat, and thus in the absence of significant personal savings a worker cooperative needs to generate sufficient income from the start to provide for their subsistence. All of this reduces the credit-worthiness of potential worker cooperatives. UBI has the potential to ease the availability of credit for worker-owned cooperatives by making a given business plan more viable since the basic subsistence needs of the worker-owners would be provided independently of market-generated income from the cooperative.

Finally, UBI also provides a basic subsidy to all kinds of activism and political participation. The long-term erosion of the dominance of capitalism requires on-going efforts at institution building from below through interstitial strategies and new state initiatives from above through symbiotic strategies. And both of these require sustained engagement by political activists both within community settings and within conventional politics.

Taken as a whole, UBI can be thought of as a mechanism for transferring a significant amount of social surplus from capital accumulation to social accumulation. There are, of course, no guarantees, but it provides funding for the human activity needed to create the building blocks of an alternative economy and society.

Now let's look at Basic Capital. Basic Capital also constitutes a significant transfer of social surplus from current uses. But how would it contribute to building alternative, noncapitalist economic relations and institutions? The principle economic uses of Basic Capital discussed by its advocates are education, housing, and small businesses. In each of these cases, the use of Basic Capital reinforces the centrality of markets as the central organising principle of economic activity: 
- Education. Basic Capital would help to cover the costs of tuition, especially in high cost private universities, or cover the costs of other kinds of training. This reinforces the model of higher education and training as services to be purchased on the market which enable individuals to invest in the improvement of their human capital. Basic Capital does improve the access to developing human capital, and thus improves justice, but it also affirms the commodified model of higher education as a private good to be paid for by individual investment. Other alternatives, such as tuition-free higher education coupled with a graduate surtax for people with higher education if their income rises above the median, would also increase access to higher education, but would do so in a way that affirms higher education as a public good and removes market principles altogether from mechanisms of access.

- Housing. In the absence of Basic Capital, young adults without relatively affluent parents often find it difficult to save enough to pay the down payments for the mortgage needed to buy a house. Basic Capital clearly improves access to mortgage markets. But again, it does so in a way that affirms the centrality of markets and private ownership as the central way that people gain access to housing. Alternatives such as creating community land-trusts to underwrite low cost housing would also increase justice, but in a way that attenuates the market-driven logic of housing.

- Small Business. Basic Capital grants at least partially solve a wealth constraint faced by many people who would like to start a small business, and in so doing they create more just conditions for the small business sector of the capitalist economy. But the majority of small businesses fail, and nothing in the Basic Capital mechanism is likely to reduce this. ${ }^{11}$ Indeed, since many people will no longer need to go a bank with a credible business plan to get a start-up loan — since they have their own Basic Capital — one might even expect the rate of failures to increase. In any case, while the presence of Basic Capital grants may change the likelihood that a person of modest means will be able to start a small business, it is unlikely to significantly increase the weight of small businesses in the overall capitalist economy. And even if it did result in a higher density of small business, this would not in any way contribute to an erosion of capitalism.

In these respects, then, Basic Capital strengthens the reproduction of capitalism by affirming the market logic of educational services and private housing and by increasing opportunities for forming small capitalist enterprises. It moves us in the direction of a more just form of capitalism, but would do little to expand the space for creating alternatives to capitalist economic activities that prefigure a more democratic and egalitarian world.

An objection to this diagnosis is that Basic Capital could also be used for anti-capitalist projects, just like Basic Income can be used for these purposes. Basic Capital, for example, could be invested, and the income stream generated by those investments could be used for all of the time-liberating capitalism-eroding purposes of Basic Income. Basic Capital could also be used directly to facilitate the formation of worker-owned co-operatives. Indeed, whereas Basic Income simply reduces the credit risk of worker cooperatives and thus makes bank loans easier to get for potential worker cooperatives, Basic Capital directly gives capital to people interested in starting a worker cooperative.

These are valid points, and thus Basic Capital could potentially be used for emancipatory purposes. However, there are three issues that suggest priority should be given to Basic Income over Basic Capital. 
First, Basic Capital is a one-shot lump-sum payment given early in adulthood. Once it is used up, that's it. Given that most business ventures fail, and in any case many people will use the Basic Capital for immediate consumption purposes, very quickly most people will lose the enhanced freedom that BC provided. Unconditional Basic Income, in contrast, is a permanent flow. It's potential for underwriting alternative life projects extends throughout the life course.

Second, UBI directly and immediately transforms one pivotal dimension of the fundamental social structure of capitalism. Regardless of how it is used, UBI changes the nature of the capitalist labour market in a way that embodies a more needs-oriented egalitarian principle of distribution and enhances individual autonomy. It directly undermines the class relations of capitalism. Basic Capital does change access to capital, but it does so in a way that in practice is likely to affirm rather than potentially undermine the market logics of the use of capital.

Finally, because of resource constraints, it is unlikely that any economy would be able to sustain both a generous Basic Income and a large enough Basic Capital grant to underwrite ambitious plans. While Basic Capital may by itself be a move in the direction of egalitarian justice, its implementation could thus constitute an obstacle for a subsequent introduction of Basic Income. Rather than being a bridge to a more expansive egalitarian project, therefore, Basic Capital could become a barrier.

Both Basic Capital and Unconditional Basic Income should be part of the egalitarian tool kit for advancing the ideals of distributive justice. But for the broader agenda of envisioning a more profoundly democratic egalitarian future, Unconditional Basic Income has greater potential to contribute to the erosion of capitalism.

Erik Olin Wright, Department of Sociology, University of Wisconsin - Madison, 8128William H. Sewell Social Sciences Building, 1180 Observatory Drive, Madison, WI 53706-1393, USA. wright@ssc.wisc.edu

\section{NOTES}

1 All of the criticisms of capitalism which follow are discussed at length in Erik Olin Wright \& Joel Rogers, American Society: How It Really Works, $2^{\text {nd }}$ edn. (New York: W.W. Norton, 2015) and Erik Olin Wright, Envisioning Real Utopias (New York: Verso, 2010), chapter 3, 'What's so bad about capitalism?' For the specific criticism of capitalism in terms of environmental destruction, see Joel Kovel, The Enemy of Nature: The End of Capitalism or the End of the World (London: Zed Books, 2007); for the critique in terms of consumerism, see Juliet Schor, True Wealth (Harmondsworth: Penguin, 2012).

2 The fundamental issue in the democracy criticism of capitalism is not mainly the problem that capitalism generates concentrations of wealth that enable wealth holders to influence politics (although of course this is also important), but rather that the expansive forms of private property rights on which capitalism depends remove crucial decisions from the public sphere.

3 I am using the term 'flourishing' as an umbrella term for the development of human capacities and the realisation of potentials. It is thus connected to the Sen and Nussbaum conception of human capabilities. My point here is not simply that capitalism may unjustly deprive some people of the resources needed to develop their capabilities, but that consumerism and hyper-competitive individualism, by shaping identities and conceptions of the good, generate biases in the kinds of potentialities people are likely to realise.

4 There is a variety of forms of the state neutrality argument some of which are consistent with mild perfectionism. My comments here are particularly relevant for versions which strongly endorse the idea that the state should not deliberately promote certain conceptions of the good life over others. 
5 Preferences for ways of life are shaped both because of adaptive preference formation - preferences adjust to what is possible - and because of socialisation and identity formation connected to capitalist-derived processes like hyper-competitive individualism.

6 Where these noncapitalist forms prefigure an emancipatory alternative, I have referred to them as 'real utopias'. For an exploration of these alternative logics of transformation, see Erik Olin Wright, Envisioning Real Utopias (New York and London: Verso, 2010).

7 For a discussion of the relative merits and viability of BI and BC, and the problem of defining the relevant magnitudes for comparisons, see Bruce Ackerman, Anne Alstott \& Philippe van Parijs, Redesigning Distribution: Basic Income and Stakeholder Grants as cornerstones for an Egalitarian Capitalism. The Real Utopias Project, vol. V (New York and London: Verso, 2006).

8 For discussions of Basic Income, see Robert Van der Veen \& Philippe van Parijs, 'A capitalist road to communism', Theory \& Society 15,5 (1986): 635-655; Philippe van Parijs, Real Freedom for All (Oxford: Oxford University Press, 1997); Erik Olin Wright, 'Basic income as a socialist project,' Basic Income Studies 1 (2006). For a general comparison of Basic Income and Basic Capital, see Ackerman, Alstott \& van Parijs op. cit.

9 See G.A. Cohen, 'The structure of proletarian unfreedom,' Philosophy E Public Affairs 12,1 (1983): 3-33.

10 For a specific discussion of the connection between UBI and freedom to say 'no,' see Karl Widerquist, Independence, Propertylessness, and Basic Income: A Theory of Freedom as the Power to Say No (New York: Palgrave Macmillan: 2013), and Philippe van Parijs, 'The universal basic income: Why utopian thought matters and how sociologists can contribute to it,' Politics and Society 41-2 (2013): 171-182.

11 According to the United States Government's Small Business Administration, 50\% of small businesses fail within 5 years and two thirds within ten years (see https://www.sba.gov/sites/default/files/FAQ_Sept _2012.pdf, p. 3). 